\title{
Moderating Effect of Exchange Rate on the Relationship Between Firm Characteristics and Financial Stability of Commercial Banks in Kenya
}

\author{
Nathan Wamalwa $^{1 *} \quad$ John Mungai $^{2}(\mathrm{PhD}) \quad$ Daniel Makori $^{2}(\mathrm{PhD})$ \\ 1.Corresponding Author: Accounting and Finance Department, School of Business, Kenyatta University, \\ Nairobi, Kenya \\ 2.Lecturer's: Accounting and Finance Department, School of Business, Kenyatta University, Nairobi Kenya
}

\begin{abstract}
The study sought to determine the moderating effect of exchange rate on the relationship between firm characteristics and financial stability of commercial banks in Kenya. The study sought to establish the effect of exchange rate on financial stability of commercial banks in Kenya. The study further sought to determine the effect of firm characteristics as a composite index on financial stability of commercial banks in Kenya. Positivism research philosophy was employed. Causal research design was utilized in this study. The study targeted 17 commercial banks from which secondary data was collected from the published financial reports for the study period between 2011 and 2018. Generalized method of moments (GMM) model guided by dynamic Panel regression analysis was utilized. Data analysis was run on the Stata 13 package and findings presented in tables while deriving conclusions and recommendations from the study findings. The study found out that exchange rate had a significant moderating effect on the relationship between firm characteristics and financial stability $(\beta=$ $0.422519, p=0.095$ ) of commercial banks in Kenya. The study also found out that firm characteristics as a composite index had a significant negative effect on financial stability $(\beta=-1.006024, p=0.063)$ of commercial banks in Kenya. The coefficient of exchange rate at $(\beta=0.0177881, p=0.000)$ shows a statistically significant positive effect on financial stability of commercial banks. To deal with issues of exchange rate fluctuations, the study recommends that commercial banks in Kenya should adopt a unified exchange rate. The study further recommends that commercial banks should focus on streamlining their internal firm characteristics in order to ensure financial stability is achieved collectively since they are associated with variability in the exchange rate.
\end{abstract}

Keywords: Moderating Effect, Exchange Rate, Firm Characteristics, Financial Stability.

DOI: $10.7176 / \mathrm{EJBM} / 12-25-07$

Publication date:September $30^{\text {th }} 2020$

\section{1Introduction}

Financial stability of a banking sector has further been noted to be influenced by external operating environment whose controls transcend the management of banks (Sumaira \& Amjad, 2013). External operating environments are the macroeconomic variables which are importantly observed by consumers, business and governments but due to their impact on the banking segment, they are focal points observed by financial institutions (Otambo, 2016). Studies have been conducted on the impact of macroeconomic variables on financial stability of financial institutions to be specific (Akram \& Eitrhelm, 2008; Pan \& Wang, 2013; Diaconu \& Onanea, 2014; Criste \& Lupu, 2014). However, many of them have ignored the exchange rate; yet it is a key component among the macroeconomic factors that affect the operations of financial institutions. An exchange rate variance has a pair impact on the financial stability of financial institutions. The immediate impact occurs when the banks do not hold the same measure of foreign currency assets and liabilities. The circuitous impact of the exchange rate fluctuations on the banks execution can be directed through its impact on the demand for credits, the degree of rivalry, and other internal aspects of banking conditions (Getachew, 2014).

The exchange rate is the cost of a unit of foreign currency as far as the domestic currency (Osundina et al., 2016). Exchange rate bridges the essential connection between the neighbourhood and the abroad market for different merchandise, services and financial assets (Reid \& Joshua, 2004). Exchange rate fluctuations might influence the price of domestic products, export, import and foreign direct investment (FDI). This in turn might affect banks' portfolio and operations such as hedging and speculation (Leyla, 2015). Exchange rate fluctuations in Kenya have been varying with times of quick devaluation of the residential currency Kenya shilling, unfavourably influencing the Kenyan economy (Ahmed, 2015). Fluctuations of exchange rate will definitely impact the foreign liabilities in commercial banks in Kenya, and thus bring about foreign exchange risk. This study further extended its frontiers through determining the moderating effect of exchange rate on the relationship between firm characteristics and financial stability of commercial banks in Kenya.

\subsection{Firm Characteristics}

Firm characteristics are the internal variables that are attributed to financial stability of a bank. "Bank" and "Firm" 
characteristics have been used interchangeably in literature. Nonetheless, they denote to a common denominator (Mdoe, 2017). Okpanachi, Doha and Mohammed (2018) describe firm characteristics as variables that are majorly under the control of a firm's management. Kariuki (2016) describes firm characteristics as the aspects of a company that are affected by firm-level management. On the other hand, Kandiru, Gachunga, Muturi and Ogutu (2015) points out firm characteristics as the demographic and managerial variables comprising internal environment of the firm. Furthermore, firm characteristics are key attributes of an organization that can influence its performance (Ondigo, 2016).

Kaguri (2013) contends that firm characteristics such as diversification, liquidity, profitability, assets, capital, institutional shareholding, leverage, age of firm, board composition, and growth and economic environmental variables have an impact on a business's monetary performance and its going concern. Gulzara, Hongxing and Muhammad (2018) assert that bank characteristics such as operational efficiency, diversification, funding cost, market power and liquidity have an effect on the stability of a financial institution. Athanasoglou, Sophocles and Matthaios (2008) consequently points out that firm characteristic can also be referred to as micro or internal factors that emanate from the financial statements such as statement of financial position and income statements. This study employed a firm characteristics as composite index as derived from the Camel variables. This was further significant in ascertain the collective effect of Camel variables as firm characteristics on financial stability of commercial banks in Kenya.

\subsection{Objectives of the Study}

The following objectives were used in the study:

(i) To determine the moderating effect of exchange rate on the relationship between firm characteristics index and financial stability of commercial banks in Kenya.

(ii) To determine the effect of firm characteristics on financial stability of commercial banks in Kenya.

(iii) To establish the effect of exchange rate on financial stability of commercial banks in Kenya.

\subsection{Research Hypotheses}

The study tested the null hypothesis

H01: Exchange rate has no significant moderating effect on the relationship between firm characteristics and financial stability of commercial banks in Kenya.

H02: Firm characteristics have no significant effect on financial stability of commercial banks in Kenya.

H03: Exchange rate has no significant effect on financial stability of commercial banks in Kenya.

\subsection{Empirical Literature Review}

Merz (2017) sought to determine exchange rate and financial stability of international developed markets in European nations. Exchange rate was used as the explanatory variable and currency as a measure. NPL ratio was used as proxy of financial stability which was also the predicator variable for the study. GMM's model was used to ascertain the relationship between the study variables. The study was carried out between 2000 and 2014 across 62 countries in Europe. GMM model was employed to take care of endogenity bias that is omitted variable, measurement errors and reverse causality in the study. From the findings, exchange rate had a significant positive effect on NPLs. The study was conducted in European nations which are developed countries, unlike Kenya which is a developing country whose political, social and economic environments are different. In addition, fragility index was used as proxy to financial stability.

Al Homaidi, Tabash, Farhan and Almaqtari (2019) sought to examine the effect of exchange rate on financial stability of Indian commercial banks listed on Bombay Stock Exchange. The study also looked at the effect of the bank specific factors on financial stability of commercial banks in India. Exchange rate was employed as an explanatory variable and financial stability as the dependent variable proxied by liquid assets to total assets. GMM model was employed for data analysis. The data was extracted from 37 commercial banks trading on Bombay Stock Exchange between 2008 and 2017. From the findings the study found out a statistically significant positive effect of exchange rate on liquidity risk of commercial banks trading on Bombay Stock Exchange. The current study, however, employed exchange rate as a moderating variable on the relationship between firm characteristics and financial stability of commercial banks in Kenya.

Rizeanu, Majerbi and Chung (2015) assessed exchange risk premium and firm characteristics of firms in South Korea. Foreign ownership, firm size and liquidity were used as proxies of firm characteristics in the study. Cross-sectional data was carried out from Korea stock market at industry and firm levels. Panel regression model was employed to aid in inferential statistics in the study. From the findings, it emerged that exchange risk premium had a statistically significant positive effect on firm liquidity while exchange risk premium had a statistically significant negative effect on foreign ownership and firm size. The study was carried out in South Korea which is a more developed country than Kenya in terms of market size, market transparency and market liquidity. Furthermore, the GMM model was used in the analysis. 
Wibowo and Anggono (2016) sought to investigate exchange rate and bank specific factors on capital adequacy of commercial banks in Indonesia. The study investigated the effect of cost to income, external funding ratio, non-performing loans, return on asset, return on equity, bank size, risky liquid asset, less risky liquidity asset and Rupiah exchange rate on capital adequacy on Indonesia commercial banks. The study was carried out between 2008 and 2014 from 19 commercial banks in Indonesia. From the findings, external funding ratio had a positive and insignificant effect on capital adequacy. Rupiah exchange rate and NPLs had insignificant negative effect on capital adequacy. Less risky liquidity asset risky liquid asset ROE had a positive and significant effect on capital adequacy. Bank size, cost to income and ROE had a negative and significant effect on capital adequacy.

Lagat and Nyandema (2016) sought to investigate exchange rate on profitability of commercial banks listed at NSE. The study employed ROE and return on capital employed of profitability in the study. Multivariate linear regression model was employed to ascertain the relationship between the study variables. Listed commercial banks at the NSE were the target population. Data was extracted from the financial statements at the custody of CBK database within 2006 and 2013. The study found out that the exchange rate had a statistically insignificant positive effect on the profitability indicators. The study concluded that the positive relationship implies that exchange volatility could have contributed to banks' profitability. However, the impact was not significant. The current study was carried out incorporating all the commercial banks in Kenya. Furthermore, the GMM model was utilized.

Getachew (2015) sought to examine the impact of exchange rate on profitability of commercial banks in Ethiopia. USD to ETB was used as a measure to exchange rate in the study while ROE was employed as a proxy to profitability in the study. Panel data was extracted from the financial statements of the commercial banks in Ethiopia. The study was carried from 2004 and 2014. From the empirical findings, the study found out that exchange rate had a statistically significant negative effect on profitability measured by ROE in the study. The current study was carried out in commercial banks in Kenya between 2011 and 2018. Furthermore, Stata software was employed as a statistical tool to ascertain the relationship between the study variables. In addition, GMM model was employed in the current study. The current study utilized exchange rate as a moderating variable.

Simiyu and Ngile (2015) sought to examine the effect of exchange rate on profitability of listed commercial banks in Kenya. Panel regression model was used in data analysis. Exchange rate was employed as the explanatory variable and measured by Ksh. to dollar rate while profitability was the dependent variable measured by ROE. The study was carried out among the 11 listed commercial banks on NSE from 2001 to 2012. The study further examined the effect of GDP and interest rate on profitability of listed commercial banks in Kenya. From the findings, the study found out that exchange rate had a statistically significant positive effect on profitability of commercial banks listed at the Nairobi Securities Exchange. Exchange rate was employed as a moderator variable in the study.

\subsection{Conceptual Framework}

Independent Variables

Dependent Variable

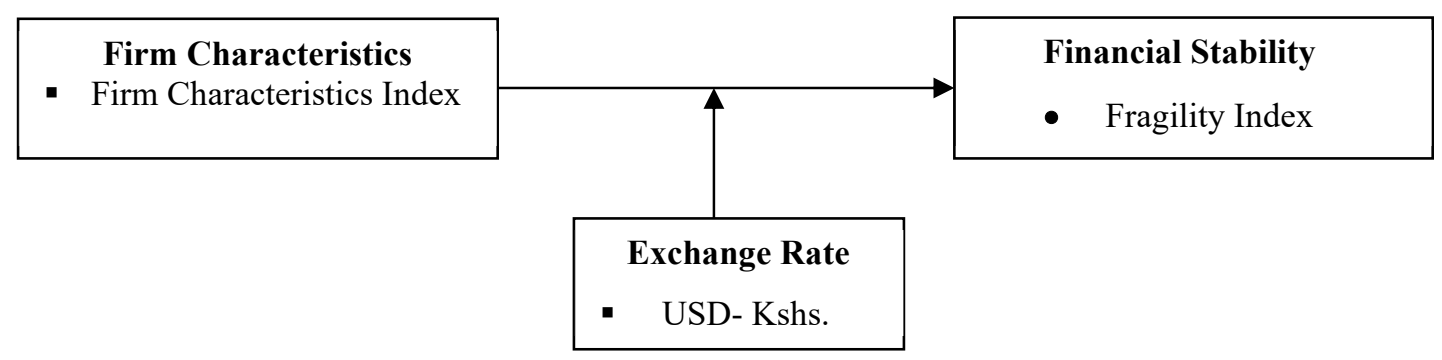

Moderating Variable

Figure 1.1 Conceptual Framework

\section{Source: Researcher (2019)}

\subsection{Research Methodology}

Positivism research philology was employed while generalized method of moments (GMM) model was utilized. In this study, causal research design was employed that sought to determine the moderating effect of exchange rate on the relationship between firm characteristics and financial stability of commercial banks in Kenya. This design determines reasons for current status of the phenomena under study. The variables of interest may not be manipulated as in experimental research (Cooper \& Schindler, 2009). The target population for this study comprised of seventeen (17) fragile commercial banks and the study was carried between 2011 and 2018. 
Secondary data was extracted from the financial statements of the respective commercial banks.

The study employed Whisman and Mccelland (2005) moderating approach. This approach is appropriate in testing for moderation and it is done by regressing the dependent variable on the independent variables, that is, regressing financial stability on the firm characteristics (FM) and the moderating variable. To determine the moderation effect of exchange rate on the relationship between FM and financial stability of commercial banks in Kenya, the study applied equation (1) as follows:

$\mathrm{FI}$ it $=\beta 0+\beta$ i FIit $-1+\beta 1 \mathrm{FMCCI}$ it $+\beta 2 \mathrm{EXR}$ it $+\beta 3\left[\mathrm{FMCCI}^{*} \mathrm{EXR}\right]+u i+\varepsilon i \mathrm{t}$

Where:

FI $i t=$ Fragility Index of commercial bank $i$ at time $t$

$\mathrm{EXR}=$ Exchange rate (Moderating Variable)

FMCCI $=$ Firm characteristics Composite Index

FMCCI*EXR $=$ Interaction between FMMCI and Exchange rate

$\beta 0=$ Constant term

yit -1 = Lagged dependent variable

$\beta \mathrm{s}=$ Coefficients of explanatory variables

$u i=$ unobserved time invariant

$\varepsilon i$ it $=$ Disturbance term

\subsection{Findings and Discussions}

\subsection{Test for Moderating Effect of Exchange Rate}

The study tested the moderating effect of exchange rate on the relationship between firm characteristics and financial stability. According to Whisman and Mcclelland, (2005) this test is appropriate while testing for moderation and it is done by regressing the dependent variable on the independent variables; that is, regressing financial stability on the firm characteristics (FMs) and the moderating variable.

Table 1: Effect of Exchange Rate on the Relationship between Firm Characteristics and Financial Stability measured by Fragility Index

\begin{tabular}{|lcccc|}
\hline Fragility Index & Coef. & Std. Err & $\mathbf{z}$ & $\mathbf{P}>|\mathbf{z}|$ \\
\hline Fragility Index L1. & $0.8097511^{*}$ & 0.0560347 & 14.45 & 0.000 \\
FMCCI & $-1.006024 *$ & 0.5411119 & -1.86 & 0.063 \\
Exchange Rate & $0.0177881^{*}$ & 0.00393 & 4.53 & 0.000 \\
FMCCI*Exchange Rate & $0.422519 * *$ & 0.2534393 & 1.67 & 0.095 \\
cons & -2.394236 & 0.3995921 & -5.99 & 0.000 \\
\hline Wald chi2(6) $=4508.93$ & & & \\
Prob $>$ chi2 $=0.0000$ & & & \\
$(*)(*)$ denote 5\% and 10\% level of significance respectively & & \\
\hline
\end{tabular}

\section{Source: Researcher (2019)}

Based on the result in Table 1, the following model 3.8a was formulated:

FI it $=-2.394236+0.8097511$ FIit $-1+-1.006024$ FMCCI it +0.0177881 EXR it +0.422519 [FMCCI* EXR] it

$+u i+\varepsilon i t$

Where:

FI ${ }_{\text {it }}=$ Fragility index at commercial bank $i$ and time $t$

FIit ${ }_{-1}=$ Lagged fragility index at commercial bank $i$ and time $t$

FMCCI $=$ Firm Characteristics Composite Index of Bank $i$ at time $t$

$\mathrm{EXR}=$ Exchange Rate of Bank $i$ at time $t$ (Moderator Variable)

Cons $=$ Constant

The result in Table 1 indicates Wald chi2 of 4508.93 with a $p$ value of 0.000 which is less than 0.05 . This indicates that fragility index lag one, firm characteristics and exchange rate as a moderator were jointly significant in explaining variations in financial stability. From the findings the fragility index lag 1 had a significant $p$ value $(0.000<0.05)$. It implies that the previous year's fragility index had an accrued effect on the following year's fragility index thus financial stability.

The coefficient of firm characteristics index $(\beta=-1.006024,0.063,<0.05)$ shows that firm characteristics have a statistically significant negative effect on financial stability of commercial banks in Kenya. The regression coefficient of -1.006024 obtained in this case implies that a unit increase of the firm characteristics index would lead to a 1.006024 decrease in fragility index and thus financial stability. A decrease in fragility index shows that a commercial bank is financially stable. The coefficient of exchange rate at $(\beta=0.0177881, p=0.000,<0.05)$ shows that exchange rate has a statistically significant positive effect financial stability of commercial banks in Kenya. This indicates that exchange rate does directly affect the financial stability of commercial banks and thus can moderate the relationship between firm characteristics index and financial stability. This finding is in agreement with those of Al Homaidi, Tabash, Farhan and Almaqtari (2019) and Merz (2017). 
The study computed FMCCI which was the composite index of firm characteristics (Camel Variables) while EXR is the exchange risk. Composite Indices was constructed based on the weighted arithmetic mean of the five variables as firm characteristics (Camel). (FMCCI*EXR) was the composite index of firm characteristics multiplied by the moderating variable exchange rate. The findings in Table 1 indicated that when firm characteristics index and exchange rate are interacted (FMCCI*EXR) had a positive and significant relationship between firm characteristics and financial stability. The composite variable for firm characteristics (FMCCI*EXR) had coefficient of 0.422519 and p-value of 0.095 implying it was statistically significant at $10 \%$ significance level. The finding implied that exchange rate significantly moderates the relationship between firm characteristics and financial stability. Hence the null hypothesis that exchange rate does not have a significant moderating effect on the relationship between firm characteristics and financial stability of commercial banks in Kenya was rejected. The regression coefficient of -2.394236 under constant indicates the value of financial stability when firm characteristics and exchange rate as moderator variable were zero.

\subsection{Conclusions and Recommendations}

The study concluded that exchange rate significantly influence the relationship between firm characteristics and financial stability of commercial banks in Kenya. The study also concluded exchange rate when interacted with the firm characteristics index is statistically significant and that the positive coefficient is different from zero. Thus, an increase in the exchange rate had an effect on financial stability of commercial banks in Kenya. Exchange rate increase would directly affect foreign liabilities held by commercial banks. By extension, the operating expense would increase due to the increase in the unaccounted costs due to increase in exchange rates.

Based on the findings, to deal with issues of exchange rate fluctuations, the study recommends that commercial banks in Kenya should adopt a unified exchange rate. The study further recommends that commercial banks should focus on streamlining their internal firm characteristics in order to ensure financial stability is achieved collectively since it is associated with variability in the exchange rate.

\section{References}

Al Homaidi, A E Tabash, M.I Farhan, H, N., \& Almaqtari, A. F. (2019). The determinants of liquidity of Indian listed commercial banks: A panel data approach. Cogent Economics \& Finance, 7(3), 1-20.

Ahmed, A. (2015). The effect of foreign exchange exposure on the financial performance of commercial banks in Kenya. International Journal of Scientific and Research Publications, 5 (11), 70-79.

Athanasoglou, P. Brissimis, S., \& Delis, M. (2008). Bank-specific, industry-specific and macroeconomic determinants of bank profitability. Journal of International Financial Markets, Institutions, and Money, 18(1), 121-36.

Central Bank of Kenya. (2016). Bank Supervision Annual Report. Nairobi, Kenya

Criste A., \& Lupu, 1, (2014).The central bank policy between the price stability objective and promoting financial stability. Procedia Economics and Finance, 8 ( 2014 ), 219 - 225

Cooper, R. D., \& Schindler, S.P. (2008). Business research methods (8th Ed.). Boston: Irwin McGraw-Hill.

Diaconua, R. I., \& Oaneab. D, C. (2014). The main determinants of bank's stability: Evidence from Romanian Banking Sector Faculty of Economics and Business Administration 21st International Economic Conference. Romania Procedia Economics and Finance Journal, 16 (9), 329 - 335.

Getachew, T. (2015). The impact of exchange rate on profitability of commercial banks in Ethiopia (MSc Thesis). Addis Ababa University, Addis Ababa, Ethiopia.

Gulzara, T., \& Hongxing, Y., \& Muhammad, H. (2018). Profitability determinants of financial institutions: Evidence from Banks in Pakistan. International journal of Financial Studies., 6 (53), 90-95.

Lagat, C. C., \& Nyandema, M. D. (2016). The influence of foreign exchange rate fluctuations on the financial performance of commercial banks listed at the Nairobi Securities Exchange. British Journal of Marketing Studies, 4 (3), 1-11.

Leyla, A. (2015). Effect of foreign exchange exposure on the financial performance of commercial banks in Kenya. International Journal of Scientific and Research Publications, 5 (11), 70-83.

Rizeanu, S., Majerbi, B., \& Chung, H. (2015). Exchange risk premium and firm characteristics. Emerging Markets Review, 7 (22), 96-125.

Simiyu, C. N., \& Ngile, L. (2015). Effect of macroeconomic variables on profitability of commercial banks listed in the Nairobi Securities Exchange. International Journal of Economics, Commerce and Management. 3 (4), $1-6$

Sumaira, B., \& Amjad, T. (2013). Determinants of profitability panel data evidence from insurance sector of Pakistan. Elixir Financial International Management Journal, Pakistan. 57A, 14377-14382.

Whisman, M. A., \& McClelland, G. H. (2005). Designing, testing, and interpreting interactions and moderator effects in family research. Journal of Family Psychology, 19(1), 111-120.

Wibowo, A., \& Anggono, H. (2016). The influence of bank specific variables and exchange rate on capital 
adequacy ratio in 19 commercial banks in Indonesia. International Conference on Management in Emerging Markets (ICMEM).

Mdoe, J. (2017). Competition and profitability of commercial banks in Kenya (Doctoral Thesis). Kenyatta University, Nairobi, Kenya.

Kariuki, W. P. (2016). Firm characteristics and financial intermediation efficiency of deposit taking saving and credit co-operative societies in Kenya (Doctoral Thesis), Jomo Kenyatta University of Agriculture and Technology, Nairobi, Kenya.

Kandiru, E. M., Gachunga, H., Muturi, W., \& Ogutu, M. (2015). Influence of firm characteristics on the impact of disclosure and transparency in the performance of companies listed in Nairobi Securities Exchange. International Journal of Scientific Research and Management, 4 (9) 67-71.

Kaguri, A. (2013) Relationship between firm characteristics and financial performance of life insurance companies in Kenya (Master's Thesis). University of Nairobi, Nairobi, Kenya.

Ondigo, H. O. (2016). Corporate governance, risk management, firm characteristics and financial performance of commercial banks in Kenya (PhD Thesis), University of Nairobi, Nairobi, Kenya.

Okpanachi, J., Doha, C., \& Mohammed, N. A. (2018). Effect of firm characteristics on profitability of listed consumer goods companies in Nigeria. Journal of Accounting, Finance and Auditing studies, 6(4) 67-78. 